JPPMS, Vol. 5, No. 1, 2021

Jurnal Penelitian Pendidikan Matematika dan Sains

http://journal.unesa.ac.id/index.php/jppms/

\title{
Kemampuan Komunikasi Matematis dalam Menyelesaikan Soal Transformasi Geometri Ditinjau dari Gender
}

\author{
Oleh: \\ Rizky Dian Pertiwi ${ }^{1}$, Tatag Yuli Eko Siswono ${ }^{2}$ \\ ${ }^{1,2}$ Jurusan Matematika FMIPA Universitas Negeri Surabaya \\ ${ }^{1}$ rizkypertiwi16030174071@mhs.unesa.ac.id \\ 2ªtagsiswono@unesa.ac.id
}

\begin{abstract}
Abstrak - Kemampuan komunikasi matematis adalah kecakapan seseorang dalam menggunakan istilah matematika untuk menyalurkan pemikirannya secara sistematis baik secara lisan maupun tulis. Kemampuan komunikasi matematis dapat diketahui dari kemampuan siswa dalam menyelesaikan soal matematika dan kemampuan dalam mengkomunikasikan hasilnya kepada orang lain. Pengetahuan mengenai transformasi geometri berperan penting dalam perkembangan matematika siswa di sekolah karena dapat membangun kemampuan spasial, kemampuan penalaran serta membantu siswa dalam menganalisis situasi matematis. Penelitian ini bertujuan untuk mendeskripsikan kemampuan komunikasi matematis dalam menyelesaikan soal transformasi geometri yang ditinjau dari gender. Jenis penelitian ini adalah penelitian kualitatif dengan pendekatan deskriptif. Subjek penelitian ini adalah dua orang siswa laki-laki dan dua orang siswa perempuan di salah satu sekolah menengah Kota Mojokerto dikarenakan penelitian ini mendeskripsikan bagaimana kemampuan komunikasi matematis yang ditunjukkan oleh siswa laki-laki dan perempuan. Berdasarkan analisis data dalam penelitian dapat disimpulkan bahwa (1) Kemampuan komunikasi matematis siswa lakilaki lebih unggul dibandingkan siswa perempuan dalam kemampuan menyajikan informasi serta dalam kemampuan menggunakan bahasa matematika yang logis dan sistematis dalam proses penyelesaian soal. Sedangkan pada kemampuan menggunakan representasi matematis dalam menyatakan gagasan matematis untuk menyelesaikan soal transformasi geometri, siswa laki-laki dan perempuan memiliki kemampuan yang sama. (2) Siswa laki-laki lebih mampu menyelesaikan soal transformasi geometri dengan lebih tepat dibandingkan siswa perempuan. (3) Siswa laki-laki lebih unggul dalam menjawab soal secara tertulis, sedangkan siswa perempuan memiliki kemampuan yang baik dalam menyajikan jawaban secara lisan atau verbal.
\end{abstract}

Kata kunci: kemampuan komunikasi matematis, transformasi geometri, gender.

Abstract - Mathematical communication skills are a person's ability to use mathematical terms to express their thoughts systematically both spoken and written. Mathematical communication skills can be seen from the ability of students to solve mathematic problems and the ability to communicate the results to others. Knowledge of geometric transformations plays an important role in the development of student's mathematics in school because it can build spatial abilities, reasoning abilities and help students analyze mathematical situations. This study aims to describe written mathematical communication skills in solving geometric transformation problems in terms of gender. This type of research is a qualitative research with a descriptive approach. The subjects of this study are two male students and two female students in one of senior high school in Mojokerto because this study describes how mathematical communication skills are showed by male and female students. The results showed that (1) Male students' mathematical communication skills are superior to female students in the ability to present information and in the ability to use logical and systematic mathematical language in the problem solving process. Meanwhile, the ability to use mathematical representations in expressing mathematical ideas to solve geometric transformation problems, male and female students have the same abilities. (2) Male students are more able to solve geometric transformation problems more precisely than female students. (3) Male students are superior in answering questions in writing, while female students have good abilities in present the answer orally or verbally.

Keywords: mathematical communication skills, problem solving, gender. 


\section{Pendahuluan}

Matematika berperan besar dalam perkembangan teknologi. Salah satu bidang yang dianggap penting dalam pelajaran matematika adalah geometri. Risnawati (2012) mengatakan bahwa geometri jika dilihat dari sudut pandang psikologi merupakan penyajian abstraksi dari pengalaman visual dan spasial, misalnya bidang, pola, pengukuran dan pemetaan. Kemampuan geometri yang perlu dimiliki siswa sekolah menengah salah satunya adalah aplikasi transformasi dan menggunakannya secara simetris untuk menganalisis situasi matematika (NCTM, 2000).

Transformasi geometri adalah ilmu matematika yang membahas tentang pengubahan letak dan bentuk suatu bangun geometri. Pengetahuan mengenai transformasi geometri berguna bagi siswa dalam membangun kemampuan spasial, kemampuan penalaran geometri, maupun memperkuat pembuktian matematika sehingga berperan penting dalam perkembangan matematika siswa di sekolah (Edward, 1997:187). Berdasarkan penelitian yang dilakukan oleh Rahmi, dkk (2018), siswa menghadapi kesulitan dalam memahami konsep dan interpretasi objek geometri yang ditransformasikan dan menjelaskan bukti secara aljabar. Hal ini menunjukkan bahwa dalam mempelajari transformasi geometri dapat membantu siswa mengembangkan kemampuan penalaran, kemampuan spasial, serta kemampuan matematika lainnya yang dapat membantu siswa mengomunikasikan hasil penyelesaian soal kepada orang lain baik secara lisan maupun tulis.

Velentzas dan Broni (2014) mengartikan komunikasi sebagai suatu tindakan menyampaikan informasi untuk tujuan menciptakan pemahaman bersama. Hal inilah yang membuat kemampuan komunikasi sangat penting dalam setiap aspek kehidupan. Komunikasi memiliki peranan yang penting dalam membantu siswa untuk membina konsep dan keterkaitan antara ide dan bahasa abstrak dengan simbol matematika (Astuti dan Leonard, 2015). Dengan melatih kemampuan komunikasi, siswa dapat mengungkapkan maupun mengklarifikasi yang berkaitan dengan pemahaman konsep yang dipelajarinya. Kemampuan komunikasi menjadi salah satu tujuan dalam pembelajaran matematika, yaitu siswa diharapkan dapat mengkomunikasikan gagasan dengan simbol, tabel, diagram, atau media lain untuk memperjelas keadaan atau masalah (Depdiknas, 2006). Komunikasi matematika dalam pembelajaran dapat membantu guru memperoleh data kemampuan siswa dalam menginterpretasi dan mengekspresikan pemahamannya terhadap konsep dan proses matematika yang dipelajari (Purnama dan Afriansyah, 2016).

Astuti dan Leonard (2015) mendefinisikan kemampuan komunikasi matematika sebagai kemampuan untuk merepresentasikan permasalahan atau ide dalam matematika dengan menggunakan benda nyata, gambar, grafik, atau tabel, serta dapat menggunakan simbol-simbol matematika. Hal ini sejalan dengan Prayitno, dkk (2013) yang mendefinisikan komunikasi matematis sebagai cara seseorang menyatakan gagasan-gagasan matematika baik secara lisan maupun tulis yang disajikan dalam bentuk gambar, tabel, diagram, rumus, ataupun demonstrasi. Indikator kemampuan komunikasi matematis dalam penelitian ini diadaptasi dari penelitian Prayitno, dkk (2020) dan Pane, dkk (2018) yang disajikan dalam tabel berikut.

Tabel 1. Indikator Kemampuan Komunikasi Matematis

\begin{tabular}{|c|c|c|c|}
\hline No. & $\begin{array}{c}\text { Indikator Kemampuan Komunikasi } \\
\text { Matematis }\end{array}$ & Penjelasan Indikator & $\begin{array}{c}\text { Kode } \\
\text { Indikator }\end{array}$ \\
\hline 1. & Kemampuan menyajikan informasi & $\begin{array}{l}\text { Kemampuan menyatakan masalah, } \\
\text { menggambarkan atau mengekspresikan } \\
\text { masalah matematis secara tertulis maupun } \\
\text { lisan }\end{array}$ & T1, L1 \\
\hline 2. & $\begin{array}{l}\text { Kemampuan menggunakan representasi } \\
\text { matematis (rumus/ gambar/ diagram/ } \\
\text { tabel/ grafik/ model matematika) dalam } \\
\text { menyatakan gagasan matematis }\end{array}$ & $\begin{array}{l}\text { Kemampuan menggunakan representasi } \\
\text { matematis, memahami, menginterpretasi, } \\
\text { maupun mengevaluasi ide-ide matematis } \\
\text { secara tertulis maupun lisan }\end{array}$ & $\mathrm{T} 2, \mathrm{~L} 2$ \\
\hline 3. & $\begin{array}{l}\text { Kemampuan menggunakan bahasa } \\
\text { matematika (notasi/ istilah/ lambang/ } \\
\text { struktur lainnya) yang logis dan sistematis } \\
\text { dalam proses penyelesaian soal }\end{array}$ & $\begin{array}{l}\text { Kemampuan menggunakan bahasa, istilah } \\
\text { matematika, notasi dan simbol untuk } \\
\text { menyajikan ide secara tertulis maupun lisan }\end{array}$ & T3, L3 \\
\hline
\end{tabular}


Tingkat kemampuan komunikasi matematis dapat diketahui dari kemampuan siswa dalam menyelesaikan soal matematika dan kemampuan dalam mengkomunikasikan hasilnya kepada orang lain. Pembelajaran matematika tidak lepas dari kegiatan menyelesaikan soal. Menyelesaikan soal tidak hanya sebagai kegiatan menerapkan matematika, tetapi juga sebagai proses belajar matematika. Menurut Pugalee (2001) salah satu cara melatih kemampuan komunikasi matematis yaitu dengan memberikan argumen atas setiap jawaban serta memberikan tanggapan terhadap jawaban yang diberikan oleh orang lain, sehingga sesuatu yang dipelajari menjadi lebih bermakna.

Wijaya, dkk (2016) menyebutkan bahwa perbedaan gender turut andil dalam menerangkan profil seseorang dalam menyelesaikan soal dan mengkomunikasikan hasilnya, namun perbedaan ini tidak konsisten jika subjek yang diambil berasal dari kelompok umur dan kelompok budaya yang berbeda. Harahap (2019) mendefinisikan gender sebagai jenis kelamin yang mengacu pada dimensi sosial budaya seseorang sebagai laki-laki atau perempuan. Istilah gender menurut Vantina dkk (2008:89) yaitu perbedaan laki-laki dan perempuan berdasarkan jenis kelamin dalam hal sifat, peran, posisi, tanggungjawab, akses, fungsi, kontrol yang dibentuk atau dikonstruksi secara sosial. Hyde dan Mezulis (dalam Santrock, 2008:198) mengungkapkan salah satu area matematika yang diteliti perbedaan gendernya adalah keahlian visuospasial, yang mencangkup kemampuan untuk memutar obyek secara mental. Pernyataan ini didukung oleh Bastable (2002:195), yaitu laki-laki lebih unggul dalam bidang matematika dibandingkan dengan perempuan dikarenakan umumnya laki-laki memiliki kemampuan spasial yang lebih baik dibandingkan dengan perempuan, sedangkan perempuan lebih unggul dalam kemampuan verbal dibandingkan dengan laki-laki. Kemampuan mengenali ruang secara konsisten pada laki-laki lebih tinggi dari pada kemampuan perempuan yang mungkin disebabkan oleh faktor genetik. Sedangkan perempuan memiliki keunggulan dalam melihat dan kemudian mengingat kembali lokasi obyek dalam pola acak yang rumit. Pendapat ini juga didukung oleh Friedman dan Schustack (2008)

yang menyebutkan salah satu perbedaan laki-laki dan perempuan yaitu kemampuan spasial dan verbal. Selain itu Doreen Kimura (1999) juga mengungkap bahwa perempuan menunjukkan kemampuan yang lebih baik dari laki-laki dalam tes verbal-memory.

Berdasarkan permasalahan tersebut, tujuan dari penelitian ini yaitu untuk mendeskripsikan kemampuan komunikasi matematis siswa dalam menyelesaikan soal transformasi geometri ditinjau dari gender.

\section{Metode}

Penelitian ini menggunakan pendekatan kualitatif yang ditujukan untuk mendeskripsikan kemampuan komunikasi matematis dalam menyelesaikan soal transformasi geometri berdasarkan gender. Subjek dalam penelitian ini adalah dua siswa laki-laki dan dua siswa perempuan SMA kelas XI di Mojokerto yang telah menerima materi transformasi geometri. Pengambilan subjek dilakukan secara convenience dikarenakan kondisi yang tidak memungkinkan. Teknik pengambilan data pada penelitian ini dengan mengambil siswa berjenis kelamin berbeda yang telah dikelompokkan untuk mendapatkan informasi yang lebih konsisten. Kemudian peneliti memberikan tes berupa soal transformasi geometri dan wawancara pada siswa. Dua siswa perempuan dan dua siswa laki-laki dari SMA tersebut berasal dari kelas yang sama dan kriteria siswa yang dipilih adalah siswa yang memiliki kemampuan matematika yang baik serta memiliki kelancaran dan keterbukaan dalam berkomunikasi. Hal ini dilihat dari penilaian dan pengamatan saat melaksanakan Pengenalan Lapangan Persekolahan (PLP) di SMA tersebut serta berdasarkan hasil rekomendasi dari guru karena dianggap siswa tersebut memiliki kemampuan matematika yang tinggi dari masing-masing gender. Analisis data dilakukan dengan cara mendeskripsikan penyelesaian soal tertulis yang dilakukan oleh siswa berdasarkan indikator kemampuan komunikasi matematis untuk memperoleh data kemampuan komunikasi matematis tulis. Sedangkan hasil wawancara dianalisis dengan indikator kemampuan komunikasi matematis untuk memperoleh data kemampuan komunikasi matematis lisan.

Tes yang diberikan berupa tes penyelesaian soal materi transformasi geometri. Siswa diberikan empat soal transformasi geometri yang telah disusun oleh peneliti yang melibatkan materi translasi, refleksi, rotasi, dan dilatasi. Teknik analisis data dalam penelitian ini dilakukan dengan reduksi data, penyajian data, dan penarikan kesimpulan.

\section{Hasil dan Pembahasan}

Setelah peneliti melakuakn penelitian, diperoleh data mengenai kemampuan komunikasi matematis tulis dan lisan. Berikut rincian siswa yang dipilih sebagai subjek penelitian. 
Tabel 2. Subjek Penelitian

\begin{tabular}{llll}
\hline No. & $\begin{array}{l}\text { Insisial } \\
\text { Siswa }\end{array}$ & $\begin{array}{l}\text { Kategori } \\
\text { Gender }\end{array}$ & $\begin{array}{l}\text { Kode } \\
\text { Siswa }\end{array}$ \\
\hline 1. & FP & Laki-laki & SL1, SL2 \\
2. & JJ & Laki-laki & SL3, SL4 \\
3. & AR & Perempuan & SP1, SP2 \\
4. & NP & Perempuan & SP3, SP4 \\
\hline
\end{tabular}

Berikut hasil analisis dan pembahasan mengenai kemampuan komunikasi matematis siswa.

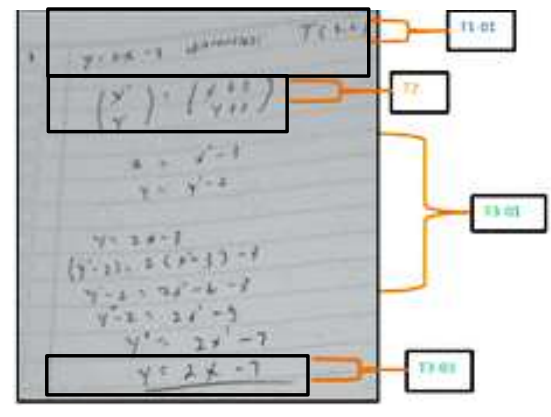

Gambar 1. Hasil Pekerjaan SL1

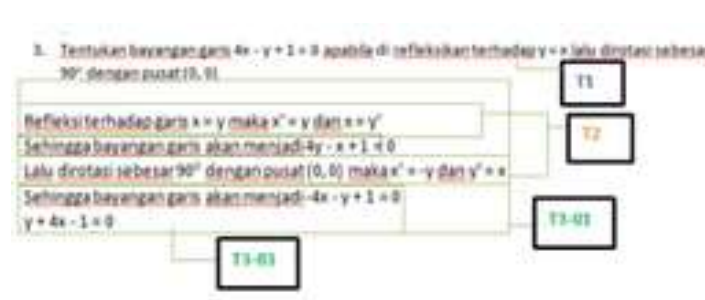

Gambar 4. Hasil pekerjaan SL4

\section{Soal 1 (Translasi)}

Hasil penyelesaian soal pada Gambar 1 digunakan untuk menganalisis kemampuan komunikasi matematis tulis siswa SL1. Sedangkan petikan wawancara berikut menunjukkan kemampuan komunikasi matematis lisan dari siswa SL1.

P-L1 : Informasi apa yang kamu ketahui dari soal?

SL1- : Kan no. 1 tentukan persamaan garis

L1 $y=2 x-3$ yang ditranslasikan oleh $(3,2)$.

P-L2 : Dalam menyelesaikan soal translasi langkah apa yang kamu gunakan?

SL1- : Pertama dicari dulu x' dan y' nya, kan L2 translasi rumusnya $x^{\prime}=x+a, y^{\prime}=$ $y+b$, lah $(\mathrm{a}, \mathrm{b})$ nya kan $(3,2)$. jadi $\mathrm{x}^{\prime}$ dan $y^{\prime}$ nya $x^{\prime}=x+3, y^{\prime}=y+2$.

P-L3 : Sekarang coba jelaskan langkah penyelesaian yang telah kamu buat.

SL1- : Kan tadi sudah dapat rumusnya, dari

L3- $\quad$ situ ketemu $x$ dan $y$ nya, lalu

01\& disubstitusi ke persamaan $y=2 x-3 . x, y$

03 nya tadi diganti sehingga menjadi ( $y^{\prime}-$

\section{A. Kemampuan Komunikasi Matematis Siswa Laki-laki dalam Menyelesaikan Soal Transformasi Geometri.}

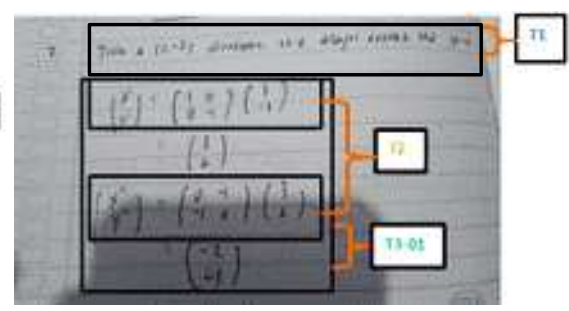

Gambar 2. Hasil pekerjaan SL2

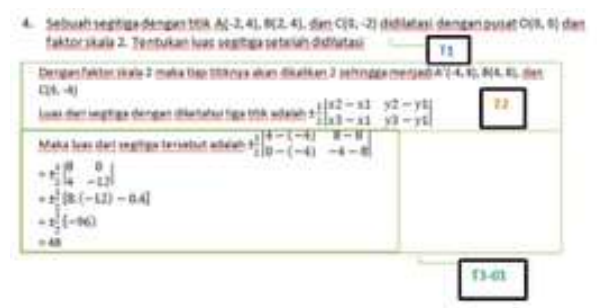

Gambar 3. Hasil pekerjaan SL3

2) $=2\left(x^{\prime}-3\right)-3 \quad \ldots \quad$ sehingga diperoleh bayangan garis $y=2 x-3$ yaitu $y=2 x-7$.

Dalam menyajikan informasi SL1 mampu menuliskan informasi yang diketahui tanpa menyertakan informasi yang ditanya, sedangkan dalam menyebutkan secara lisan SL1 mampu menyebutkan informasi pada soal secara lengkap. Dalam menggunakan representasi matematis, SL1 menuliskan rumus untuk mencari bayangan hasil translasi dari suatu titik dengan menggunakan matriks dan mampu menjelaskan secara lisan dengan sistematis berkaitan dengan rumus yang digunakan. Dalam menggunakan bahasa matematika untuk menguraikan soal, SL1 hanya menuliskan notasi dan simbol matematis tanpa menuliskan istilah matematika dalam menguraikan langkah penyelesaian, namun

pada hasil wawancara SL1 mampu menggunakan bahasa matamatika dengan melibatkan istilah dalam menjelaskan proses 
penyelesaian soal secara logis dan sistematis serta mampu menyajikan kesimpulan dengan tepat. Berdasarkan hasil tes dan wawancara, SL1 memenuhi keseluruhan indikator kemampuan komunikasi matematis dengan baik dalam menyelesaikan soal translasi.

\section{Soal 2 (Komposisi Transformasi Refleksi)}

Hasil penyelesaian soal pada Gambar 2 digunakan untuk menganalisis kemampuan komunikasi matematis tulis siswa SL2. Sedangkan petikan wawancara berikut menunjukkan kemampuan komunikasi matematis lisan dari siswa SL2.

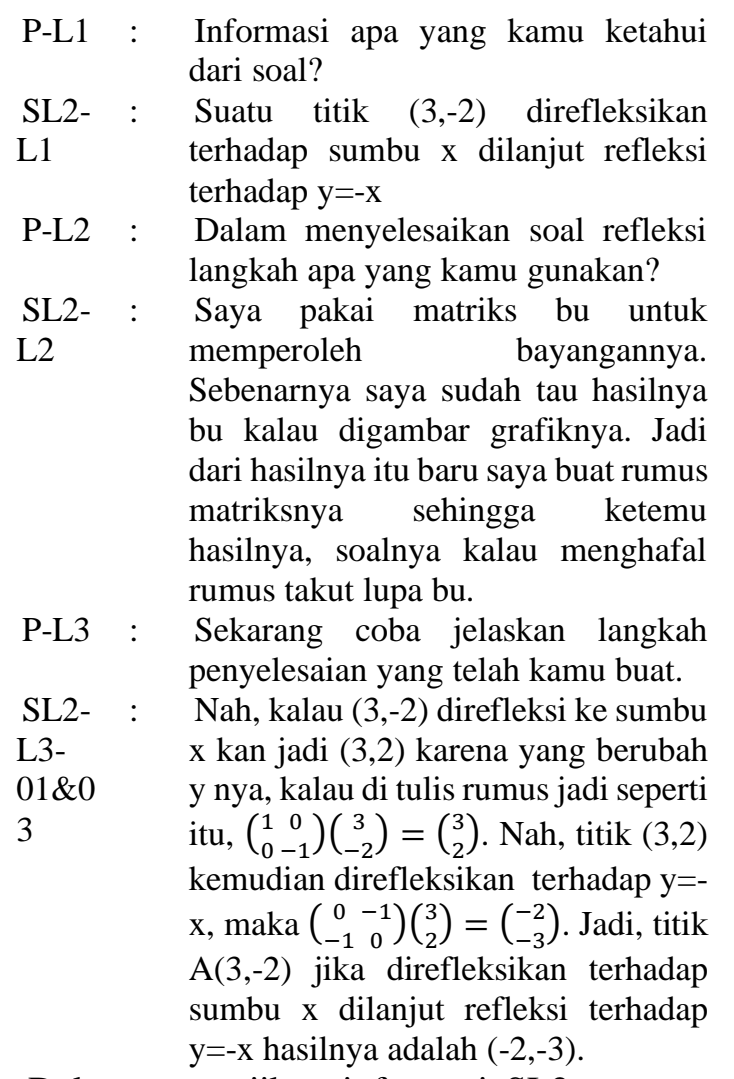

Dalam menyajikan informasi SL2 mampu menuliskan dan menyebutkan secara lisan informasi yang diketahui tanpa menuliskan informasi yang ditanya. Dalam menggunakan representasi matematis, SL2 menuliskan rumus untuk mencari bayangan hasil refleksi dengan menggunakan matriks dan mampu menjelaskan secara lisan dengan sistematis berkaitan dengan rumus yang digunakan. Dalam menggunakan bahasa matematika untuk menguraikan soal, SL2 hanya menuliskan notasi dan simbol matematis tanpa menuliskan istilah matematika dalam menguraikan langkah penyelesaian, namun pada hasil wawancara SL2 mampu menggunakan bahasa matamatika dengan melibatkan istilah dalam menjelaskan proses penyelesaian soal secara logis dan sistematis serta mampu menyajikan kesimpulan dengan tepat. Berdasarkan hasil tes dan wawancara,
SL2 memenuhi keseluruhan indikator kemampuan komunikasi matematis dalam menyelesaikan soal refleksi dengan baik.

\section{Soal 3 (Komposisi Transformasi Refleksi- Rotasi}

Hasil penyelesaian soal pada Gambar 3 digunakan untuk menganalisis kemampuan komunikasi matematis tulis siswa SL3. Sedangkan petikan wawancara berikut menunjukkan kemampuan komunikasi matematis lisan dari siswa SL3.

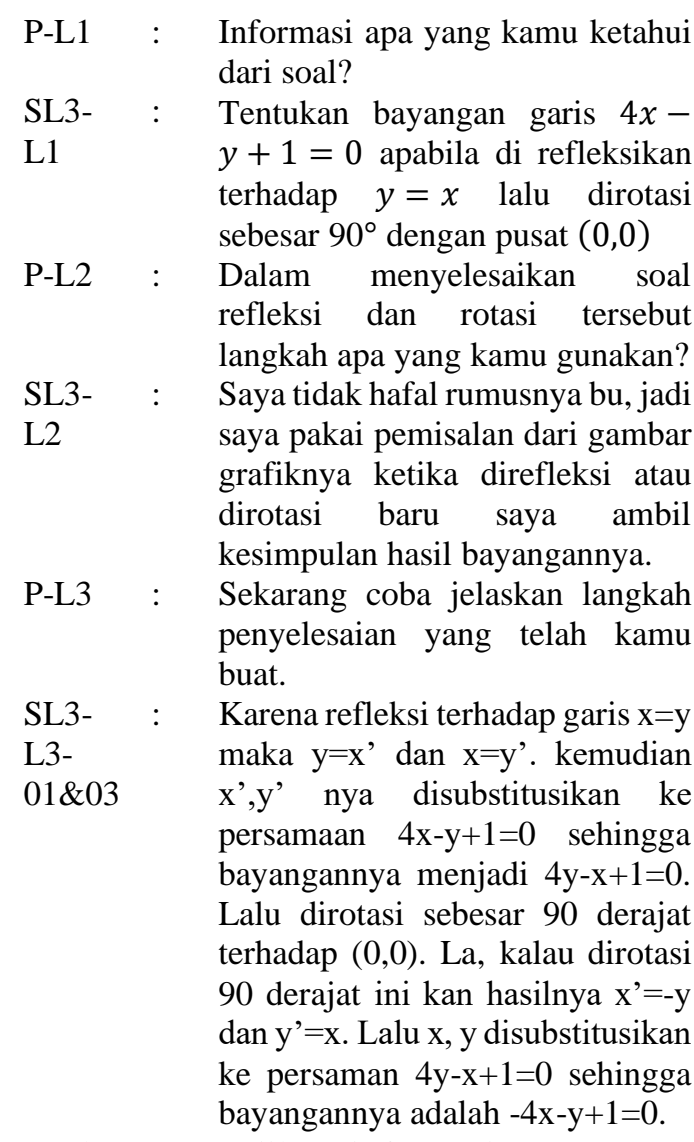

Dalam menyajikan informasi SL3 mampu menuliskan dan menyebutkan informasi lengkap secara lisan dengan menuliskan soal yang diberikan. Dalam menggunakan representasi matematis, SL3 menuliskan persamaan bayangan hasil refleksi dan rotasi serta mampu menjelaskan secara lisan dengan sistematis berkaitan dengan representasi yang digunakan. Dalam menggunakan bahasa matematika untuk menguraikan soal, SL3 mampu menggunakan notasi, istilah, dan simbol secara tepat, logis dan sistematis. Berdasarkan hasil tes dan wawancara, SL3 memenuhi keseluruhan indikator kemampuan komunikasi matematis dalam menyelesaikan komposisi transformasi refleksi-rotasi dengan baik.

Soal 4 (Dilatasi) 
Hasil penyelesaian soal pada Gambar 4 digunakan untuk menganalisis kemampuan komunikasi matematis tulis siswa SL4. Sedangkan petikan wawancara berikut menunjukkan kemampuan komunikasi matematis lisan dari siswa SL4.

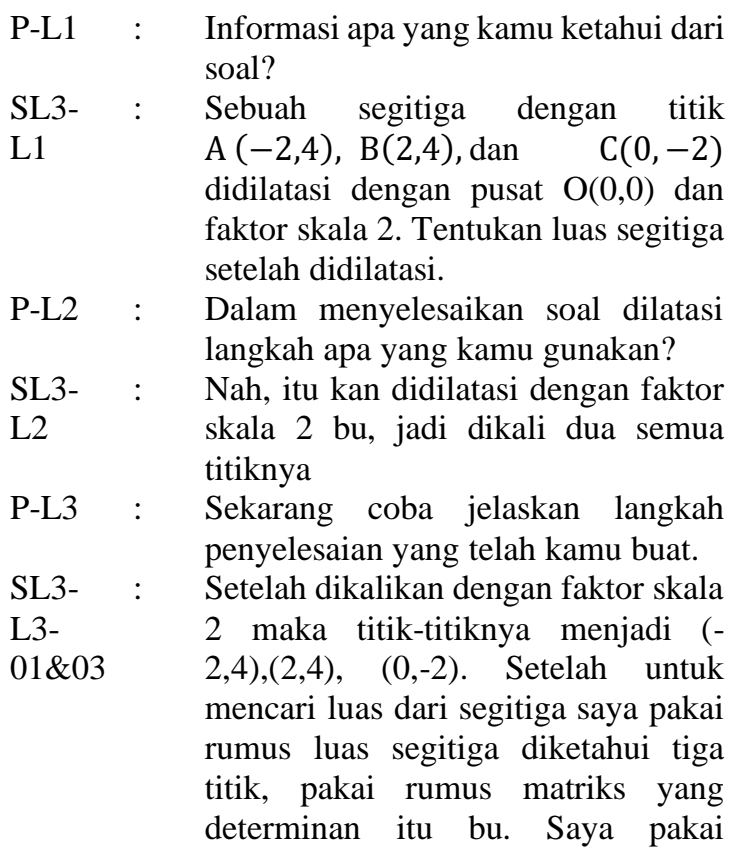

aplikasi online rumus-rumus bu jadi langsung saya tulis rumusnya. itu \pm karena determinan bisa positif bisa negatif bu. Terus dimasukkan semua titiknya .... sehingga hasil luasnya 48 .

Dalam menyajikan informasi SL4 mampu menuliskan dan menyebutkan secara lisan informasi secara lengkap dengan menuliskan kembali soal yang diberikan. Dalam menggunakan representasi matematis, SL4 menuliskan dan menjelaskan cara memperoleh hasil bayangan dilatasi dengan menggunakan rumus cepat yaitu dengan mengalikan tiap titik dengan faktor skala. Dalam menggunakan bahasa matematika untuk menguraikan soal, SL4 mampu menggunakan notasi, istilah, dan simbol secara tepat, logis dan sistematis bahkan mampu menggunakan rumus yang lebih rumit yang tidak diajarkan di sekolah. Berdasarkan hasil tes dan wawancara, SL4 memenuhi keseluruhan indikator kemampuan komunikasi matematis dalam menyelesaikan soal dilatasi.

\section{B. Kemampuan Komunikasi Matematis Siswa Perempuan dalam Menyelesaikan Soal Transformasi Geometri}
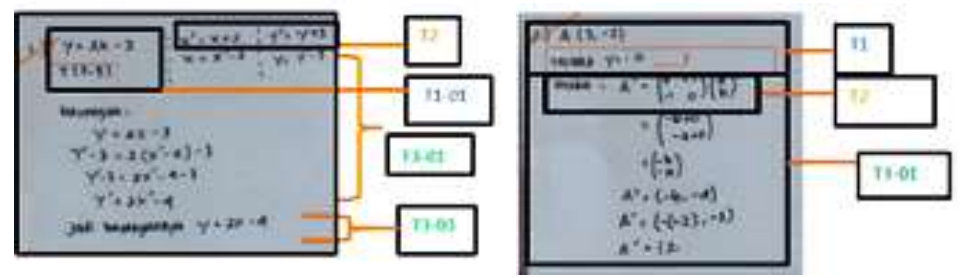

Gambar 6. Hasil Pekerjaan SP1

Gambar 5. Hasil pekerjaan SP2

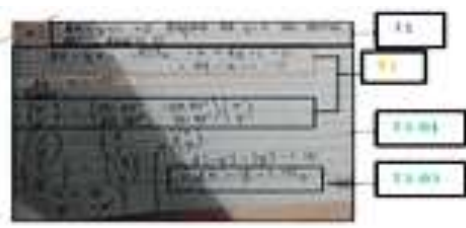

Gambar 8. Hasil pekerjaan SP3

\section{Soal 1 (Translasi)}

Hasil penyelesaian soal pada Gambar 5 digunakan untuk menganalisis kemampuan komunikasi matematis tulis siswa SP1. Sedangkan petikan wawancara berikut menunjukkan kemampuan komunikasi matematis lisan dari siswa SP1.

\footnotetext{
P-L1 : Informasi apa yang kamu ketahui dari soal?

SP1- : Diketahui sebuah garis $y=2 x-3$

L1 ditranslasikan pada titik $(2,3)$. Tentukan bayangannya.
}

Gambar 7. Hasil pekerjaan SP4

P-L1 : Coba dicek kembali pada soal yang saya berikan, apa benar sudah sesuai dengan informasi soal yang kamu tuliskan.

SP1- : Oh iya bu, kurang teliti. titiknya L1 $(3,2)$. Berarti menentukan bayangan garis $\mathrm{y}=2 \mathrm{x}-3$ jika ditranslasikan $(3,2)$.

P-L2 : Dalam menyelesaikan soal translasi langkah apa yang kamu gunakan?

SP1- : Translasi titik $(3,2)$, dari situ L2 diperoleh untuk mencari

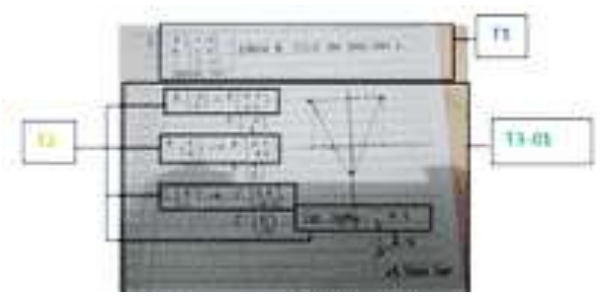




\section{bayangannya kan x' dan y', $x^{\prime}$ nya itu $x+3$ dan $y^{\prime}$ itu $y+2$ \\ P-L3 : Sekarang coba jelaskan langkah penyelesaian yang telah kamu buat. \\ SP1- : lalu didapat $x=x^{\prime}-3, y=y^{\prime}-$ \\ L3- $\quad 2$. $x$ dan $y$ nya disubstitusi ke \\ $01 \& 03$ persamaan $y=2 x-3$, berarti $\left(y^{\prime}-\right.$ 2) $=2\left(x^{\prime}-3\right)-3 \quad \ldots$ jadi bayangan garisnya yaitu $y=2 x-7$.}

Dalam menyajikan informasi, SP1 menuliskan informasi yang diketahui tanpa menyertakan informasi yang ditanya. SP1 tidak mampu menuliskan informasi dengan tepat karena kurang teliti dalam membaca informasi soal, namun SP1 mampu merevisi kesalahan tersebut dengan menyebutkan informasi secara lisan dengan tepat. Hal ini mengakibatkan siswa mengalami kesalahan dalam menyelesaikan soal karena tidak menyajikan informasi dengan teliti. SP1 juga mampu merevisi representasi matematis yang digunakan dengan menyebutkan persamaan bayangan hasil translasi dengan tepat sesuai dengan soal yang diberikan. SP1 juga mampu menjelaskan langkah penyelesaian secara lisan dengan menggunakan uraian yang logis dan sistematis serta menyebutkan kesimpulan dengan tepat. Berdasarkan penjelasan tersebut, SP1 memiliki kemampuan komunikasi matematis tulis yang kurang baik dalam indikator kemampuan menyajikan informasi sehingga mengakibatkan kesalahan dalam menyelesaikan soal. Namun SP1 mampu merevisi kesalahannya secara lisan sehingga memenuhi seluruh indikator kemampuan komunikasi matematis lisan dengan baik. Hal ini menunjukkan bahwa SP1 sebagai siswa perempuan kurang teliti dan tergesa-gesa dalam menyelesaikan soal, namun memiliki kemampuan mengingat dan menjelaskan secara verbal dengan baik.

\section{Soal 2 (Komposisi Transformasi Refleksi)}

Hasil penyelesaian soal pada Gambar 6 digunakan untuk menganalisis kemampuan komunikasi matematis tulis siswa SP2. Sedangkan petikan wawancara berikut menunjukkan kemampuan komunikasi matematis lisan dari siswa SP2.

$\begin{array}{lll}\text { P-L1 } & : & \begin{array}{l}\text { Informasi apa yang kamu ketahui } \\ \text { dari soal? }\end{array} \\ \text { SP2- } & : \quad \begin{array}{l}\text { Diketahui sebuah } \\ \text { direfleksikan terhadap y=-x }\end{array} \\ \text { L1 } & : \quad 2) & \begin{array}{l}\text { Sebentar, coba dicek kembali } \\ \text { apakah informasi yang kamu tulis } \\ \text { P-L1 } \\ \text { sudah sesuai dengan soal yang ibu } \\ \text { berikan? }\end{array}\end{array}$

SP2- : Loh, salah ta bu? Sebentar saya L1 cek dulu. Oh iya bu, berarti titik $\mathrm{A}(3,-2)$ direfleksikan ke sumbu $\mathrm{x}$ dilanjut refleksi ke $y=-x$. Berarti salah ya bu, hehe..

P-L2 : Dalam menyelesaikan soal refleksi langkah apa yang kamu gunakan?

SP2- : Saya hafal hasil bayangannya bu, L2 soalnya kelihatan dari gambar grafiknya.

P-L3 : Sekarang coba jelaskan langkah penyelesaiannya.

SP2- : Sebentar bu, ohh.. kalau L3- direfleksikan ke garis $\mathrm{x}$ kan 01\&03 bayangannya (a,-b), berarti $(3,-2)$ menjadi $(3,2)$, selanjutnya $(3,2)$ direfleksikan ke garis $\mathrm{y}=-\mathrm{x}$ kan $(-$ b,-a) berarti $(3,2)$ menjadi $(-2,-3)$. Jadi bayangan dari $(3,-2)$ setelah direfleksikan oleh sumbu $x$ dan garis $y=-x$ adalah $(3,-2)$

Dalam menyajikan informasi, SP2 tidak mampu menuliskan informasi dengan tepat karena kurang teliti dalam membaca informasi soal, namun SP2 mampu merevisi kesalahan tersebut dengan menyebutkan informasi secara lisan dengan tepat. Hal ini mengakibatkan siswa salah dalam menyelesaikan soal karena tidak memahami informasi dengan teliti. Namun SP2 mampu merevisi secara lisan tahap tersebut dengan menyebutkan informasi secara tepat. Setelah itu SP2 mampu merevisi representasi matematis dengan menyebutkan persamaan bayangan hasil refleksi dengan tepat. SP2 juga mampu menjelaskan langkah penyelesaian secara lisan dengan menggunakan uraian yang logis, sistematis dan menyebutkan kesimpulan dengan tepat. Berdasarkan penjelasan tersebut, SP2 memiiki kemampuan komunikasi matematis tulis kurang baik dalam indikator kemampuan menyajikan informasi sehingga mengakibatkan kesalahan dalam menyelesaikan soal. Namun SP2 mampu merevisi kesalahannya secara lisan sehingga memenuhi seluruh indikator kemampuan komunikasi matematis lisan dengan baik. Hal ini menunjukkan bahwa SP2 sebagai siswa perempuan kurang teliti dan tergesa-gesa dalam menyelesaikan soal, namun memiliki kemampuan mengingat dan menjelaskan secara verbal dengan baik.

\section{Soal 3 (Komposisi Transformasi Refleksi- Rotasi}

Hasil penyelesaian soal pada Gambar 7 digunakan untuk menganalisis kemampuan komunikasi matematis tulis siswa SP3. Sedangkan petikan wawancara berikut 
menunjukkan kemampuan komunikasi matematis lisan dari siswa SP3.

P-L1 : Informasi apa yang kamu ketahui dari soal?

SP3- : Diketahui garis $4 x-y+1=0$

L1 direfleksikan terhadap $y=x$ lalu dirotasi sebesar $90^{\circ}$ dengan pusat $(0,0)$

P-L2 : Dalam menyelesaikan soal refleksi dan rotasi tersebut langkah apa yang kamu gunakan?

SP3- : Kalau yang refleksi saya ingat letak L2 bayangan dari gambar grafiknya jadi mudah langsung disubstitusikan saja bu. Kalau yang rotasi saya pakek rumus $\left(\begin{array}{c}\cos a-\sin a \\ \sin a \cos a\end{array}\right)\left(\begin{array}{l}a \\ b\end{array}\right)$

P-L3 : Sekarang coba jelaskan langkah penyelesaiannya.

SP3- : refleksi terhadap garis $\mathrm{x}=\mathrm{y}$ maka $\mathrm{x}$ L3- menjadi $y$ dan $y$ menjadi $x$, lalu $01 \& 03$ disubstitusikan ke persamaan $4 x-y+1=0$ sehingga bayangannya menjadi $4 \mathrm{y}-\mathrm{x}-$ $1=0$. Lalu dirotasi sebesar 90 derajat terhadap $(0,0)$ dimasukkan ke rumus sin cos tadi lalu ketemu bayangannya disubstitusikan ke persaman $4 \mathrm{y}-\mathrm{x}-1=0$ sehingga bayangannya adalah $-4 x-y-$ $1=0$.

P-L3 : Coba dicek kembali itu $4 \mathrm{y}-\mathrm{x}-1=0$ darimana.

SP3- : Oh iya bu salah itu harusnya $4 y-x+1=0$, L3- salah di tanda operasinya. Berarti 01\&03 bayangannya setelah di refleksi dan dirotasikan hasilnya $-4 x-y+1=0$. Benar ya bu?

P-L3 : Iya benar.

Dalam menyajikan informasi, SP3 mampu menuliskan dan menyebutkan infomasi yang diketahui secara tepat tanpa menuliskan informasi yang ditanyakan. Dalam menggunakan representasi matematis, SP3 dalam menyelesaikan soal refleksi mampu menuliskan model transformasi serta menyebutkan persamaan bayangan hasil refleksi dengan tepat karena mengingat letak bayangan pada grafik. Sedangkan dalam menyelesaikan soal rotasi, SP3 menggunakan rumus matriks untuk menentukan bayangan hasil rotasi. SP3 juga mampu menjelaskan langkah penyelesaian secara lisan dengan menggunakan uraian bahasa matematika secara logis, sistematis namun kurang tepat karena kurang teliti dalam menyebutkan secara lisan dan tulis notasi yang digunakan. Berdasarkan penjelasan tersebut, SP3 memiliki kemampuan komunikasi matematis tulis yang kurang baik dalam indikator kemampuan menggunakan bahasa matematika sehingga mengakibatkan kesalahan dalam menyelesaikan soal. Namun
SP3 mampu merevisi kesalahannya secara lisan sehingga memenuhi seluruh indikator kemampuan komunikasi matematis lisan dengan baik. Hal ini menunjukkan bahwa SP3 sebagai siswa perempuan kurang teliti dalam menyelesaikan soal, namun memiliki kemampuan mengingat dan menjelaskan secara verbal dengan baik.

\section{Soal 4 (Dilatasi)}

Hasil penyelesaian soal pada Gambar 8 digunakan untuk menganalisis kemampuan komunikasi matematis tulis siswa SP4. Sedangkan petikan wawancara berikut menunjukkan kemampuan komunikasi matematis lisan dari siswa SP4.

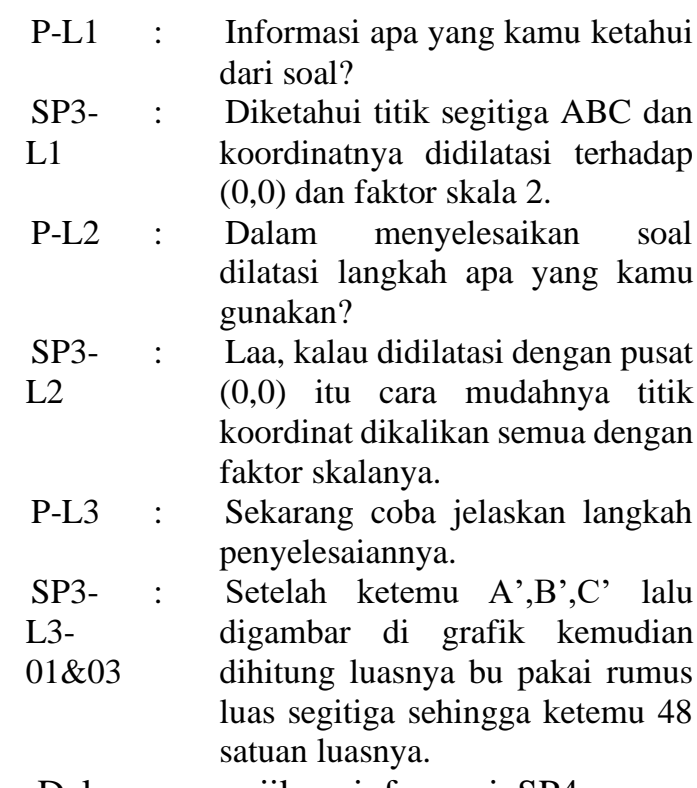

Dalam menyajikan informasi SP4 mampu menyebutkan secara lisan dan tulis informasi yang diketahui tanpa menyertakan informasi yang ditanya. Dalam menggunakan representasi matematis, SP4 menuliskan dan menjelaskan cara memperoleh hasil bayangan dilatasi dengan menggunakan rumus cepat yaitu dengan mengalikan tiap titik dengan faktor skala. Dalam menggunakan bahasa matematika untuk menguraikan soal, SP4 mampu menggunakan notasi, istilah, dan simbol secara tepat, logis dan sistematis. Berdasarkan hasil tes dan wawancara, SP4 memenuhi keseluruhan indikator kemampuan komunikasi matematis dalam menyelesaikan soal dilatasi.

\section{Pembahasan}

\section{Siswa Laki-laki}

Dalam menyajikan soal, siswa laki-laki mampu menuliskan dan menyebutkan informasi soal secara lisan dengan lengkap dan akurat. Hal ini ditunjukkan dari penyelesaian tertulis dan wawancara siswa yang 
menyebutkan informasi soal dengan tepat dan lengkap. Siswa laki-laki lebih teliti dalam membaca soal sehingga mampu menyajikan informasi dengan tepat. Hasil penelitian Aini (2017) menyebutkan bahwa siswa laki-laki memahami masalah dengan membaca berulang-ulang dan cenderung lebih lama daripada siswa perempuan. Hal ini memungkinkan laki-laki mampu memahami soal dan menyebutkan informasi dengan lebih teliti dibanding perempuan.

Dalam menggunakan representasi matematis untuk menyelesaikan soal transformasi geometri, siswa laki-laki menggunakan rumus atau langsung menuliskan persamaan bayangan dari suatu transformasi. Siswa laki-laki mengaku bahwa jika tidak menghafal rumus transformasi, hasil bayangan dapat diperoleh dari grafik dengan melakukan pemisalan suatu titik yang ditransformasikan yang menunjukkan bahwa siswa laki-laki tersebut menggunakan kemampuan penalaran dan kemampuan spasial untuk menyelesaikan soal transformasi geometri. Hasil penelitian tersebut relevan dengan pendapat Edward (1997:187) yang menyebutkan bahwa pengetahuan mengenai transformasi geometri mengembangkan kemampuan penalaran dan kemampuan spasial.

Siswa laki-laki mampu menggunakan bahasa matematika untuk menguraikan penyelesaian dengan logis dan sistematis. Siswa laki-laki lebih teliti dibandingkan siswa perempuan dalam menuliskan notasi bilangan sehingga mampu menjawab soal dengan tepat. Hal ini didukung oleh pendapat Hardy, dkk (2015) yang menyebutkan bahwa belahan otak kanan laki-laki lebih memiliki kemampuan numerik dan logika, sehingga gender laki-laki lebih mampu mengembangkan kemampuan matematika. Purwanti (2013) menyebutkan bahwa pada tes PISA 2006, laki-laki memiliki rata-rata kemampuan literasi matematika lebih tinggi daripada perempuan yang menunjukkan bahwa laki-laki memiliki kemampuan matematika lebih baik. Hal ini juga ditunjukkan dari kemampuan siswa laki-laki dalam menggunakan rumus yang lebih rumit untuk menyelesaikan soal transformasi geometri yang diberikan.

\section{Siswa Perempuan}

Dalam menyajikan informasi, siswa perempuan mengalami kesalahan karena tergesa-gesa dalam membaca dan menuliskan informasi. Berdasarkan penelitian Aini (2017) siswa perempuan dapat memahami dan sadar terhadap proses berpikirnya serta dapat menyelesaikan tugas dengan cepat. Menurut Sulistyaningsih (2017) siswa dapat mengalami kesalahan dalam memahami informasi karena siswa terbiasa mengerjakan secara langsung pada proses perhitungannya.

Dalam tahap menggunakan representasi matematis untuk menyelesaikan soal transformasi geometri siswa perempuan mampu menyajikan rumus maupun persamaan bayangan hasil transformasi yang sesuai. Bahkan jika siswa lupa dengan rumus dari suatu transformasi geometri, mereka mampu mengingat kembali dengan melakukan pemisalan pada grafik koordinat. Hal ini menunjukkan bahwa siswa perempuan juga dapat menggunakan kemampuan penalaran dan kemampuan spasial dalam menyelesaikan soal transformasi geometri, sehingga memiliki kemampuan yang sama dengan laki-laki dalam tahap menggunakan representasi matematis untuk menyelesaikan soal transformasi geometri. Dengan demikian, siswa tidak mengalami kesulitan dalam mengkomunikasikan penyelesaian soal transformasi geometri jika diajarkan cara memanfaatkan koordinat transformasi. Relevan dengan Ada dan Kurtulus (2010) yang menjelaskan bahwa dengan mempelajari transformasi geometri, siswa dapat menyederhanakan konsep geometri analitik melalui koordinat transformasi.

Pada tahap menggunakan bahasa matematis untuk menguraikan penyelesaian, siswa perempuan mampu menggunakan bahasa matematis yang berkaitan dengan notasi, simbol, dan istilah matematika dengan logis dan sistematis. Namun siswa perempuan kurang teliti dalam menuliskan notasi dan bilangan sehingga mengakibatkan salah dalam menjawab soal. Siswa perempuan memiliki kelebihan dalam mengkomunikasikan secara lisan. Hal ini ditunjukkan dari kelancaran siswa dalam merevisi kesalahannya secara verbal. Hasil penelitian ini sejalan dengan pendapat Doreen Kimura (1999) yang mengungkap bahwa perempuan menunjukkan kemampuan yang lebih baik dari laki-laki dalam tes verbalmemory.

\section{PENUTUP}

Simpulan

Berdasarkan analisis data dalam penelitian dapat disimpulkan bahwa (1) kemampuan 
komunikasi matematis siswa laki-laki lebih unggul dibandingkan siswa perempuan dalam kemampuan menyajikan informasi serta dalam kemampuan menggunakan bahasa matematika (notasi/ istilah/ lambang/ struktur lainnya) yang logis dan sistematis dalam proses penyelesaian soal. Sedangkan pada kemampuan menggunakan representasi matematis (rumus/ gambar/ diagram/ tabel/ grafik/ model matematika) dalam menyatakan gagasan matematis untuk menyelesaikan soal transformasi geometri, siswa laki-laki dan perempuan memiliki kemampuan yang sama. (2) Siswa laki-laki lebih mampu menyelesaikan soal transformasi geometri dengan lebih tepat dibandingkan siswa perempuan. (3) Siswa laki-laki lebih unggul dalam menjawab soal secara tertulis, sedangkan siswa perempuan memiliki kemampuan yang baik dalam menyajikan jawaban secara lisan atau verbal.

\section{Saran}

Berdasarkan hasil dan pembahasan penelitian yang telah dijelaskan sebelumnya, peneliti memiliki saran sebagai berikut: (1) Pembelajaran matematika di sekolah perlu diperdalam dengan penyajian konsep disamping latihan-latihan, hal ini berguna agar siswa tidak hanya bergantung pada rumus, tetapi juga mampu menyelesaikan soal berdasarkan konsep yang telah dimiliki, dan (2) guru perlu mengakomodasi kemampuan komunikasi matematis siswa agar siswa dapat berlatih menyajikan hasil berpikirnya secara ilmiah yang bermanfaat dalam kehidupan sehari-hari.

\section{Daftar Pustaka}

Ada, Tuba dan Kurtulus, Aytac., 2010. Students' misconceptions and errors in transformation geometry. International Journal of Mathematical Education in Science and Technology, vol. 41(7)

Aini, Khofidhoh N., 2017. Proses Berpikir Mahasiswa Laki-Laki dan Perempuan dengan Gaya Kognitif Field Independent dalam Memecahkan Masalah. Jurnal Inovasi Pendidikan dan Pembelajaran Matematika. Vol. 3(1)

Astuti dan Leonard, 2015. Peran Kemampuan Komunikasi Matematika Terhadap Prestasi Belajar Matematika Siswa. Jurnal Formatif 2(2): $102-110$

Bastable, Susan B., 2002. Perawat Sebagai Pendidik: Prinsip-prinsip Pengajaran \& Pendidikan. Jakarta: EGC. terjemahan oleh Wulandari dan Widiyanto. (Online) diakses pada 16 April 2020 tersedia: : https://books.google.co.id/books?id=dyG0u IBfSWkC\&pg=PA191\&dq=pengaruh+gen der+terhadaasp+pembelajaran\&hl=en\&sa= X\&ved=0ahUKEwiOl7SckvoAhVFX30KHW2DATcQ6AEINDAB\#v =onepage \&q=gender\&f=false

Depdiknas, 2006. Kurikulum Tingkat Satuan Pendidikan (KTSP). Jakarta: Direktorat Jendral Pendidikan Dasar dan menengah.

Doreen Kimura, Sex and Cognition, Cambridge and London: The MIT Press, 1999

Edwards, L.D., 1997. "Explore Ring the Terrority before Proof: Students' Generalization in a computer Microworld for Transformation Geometry". International Journal of Computers for Mathematical Learning, 1:187-215

Friedman, Howard S., Schustack, Miriam W. 2008. Kepribadian (Teori Klasik dan Riset Modern), Alih Bahasa: Benedictine Widyasinta, Edisi Ketiga, Jakarta, Erlangga.

Harahap, 2019. Gender Typing (Pada Anak Usia Sekolah Dasar). Jurnal Ilmu-Ilmu Sosial dan Keilmuan. Vol.1 (2)

Hardy, Hudiono, B., dan Rajiin, M., 2015. Pengaruh Gender dan Strategi Pembelajaran Terhadap Kemampuan Pemecahan Masalah Matematis Siswa. Jurnal Pendidikan dan Pembelajaran Khatulistiwa, vol 4 (9).

NCTM, 2000. Principles and standards for teaching school mathematics. Restorn:NCTM

Pane, N. S., Jaya I., dan Lubis M. S., 2018. Analisis Kemampuan Komunikasi Matematis Siswa Pada Materi Penyajian Data di Kelas VII Mts Islamiyah Medan. AXIOM, vol. 8 (1)

Pugalee, D.A. (2001). Using Communication to Develop Students' Mathematical Litarcy. JRME. V6 January 2001.

Purnama, Imas L., dan Afriansyah, Ekasatya A., 2016. Kemampuan Komunikasi Matematis Siswa ditinjau Melalui Model Pembelajaran Kooperatif Tipe Complete Sentence Dan Team Quiz. Jurnal Pendidikan Matematika Sriwijaya, vol. 10 (1)

Purwanti, Kristi L. 2013. Perbedaan Gerner terhadap Kemampuan Berhitung Matematika Menggunakan Otak Kanan pada Siswa Kelas I. SAWWA: Vol 9(1) 
Prayitno, S., Suwarsono, S., dan Siswono. T. Y., 2013. Identifikasi Indikator Kemampuan Komunikasi Matematis Siswa dalam Menyelesaikan Soal Matematika Berjenjang pada Tiap-Tiap Jenjangnya. Konferensi Nasional Pendidikan Matematika V. Universitas Negeri Malang Tanggal 27-30 Juni 2013.

Prayitno, S., Suwarsono, S., dan Siswono, T. Y., 2020. Mathematical Communication Ability of Junior High School Students in Solving Mathematics Problems. International Journal of Advanced Science and Technology Vol. 29 (5)

Rahmi, A., Armiati A., dan Syarifuddin H., 2018. Mathematics learning media development of based computer on translation context in senior high school. International Conferences on Educational, Social Sciences and Technology

Risnawati. (2012). Pengaruh Pembelajaran dengan Pendekatan Induktif-Deduktif Berbantuan Program Cabri Geometry terhadap Peningkatan Kemampuan Representasi Matematis Siswa Sekolah Menengah Pertama. Tesis SPs UPI. Bandung. Tidak Diterbitkan.

Santrock, John W., 2008. Psikologi Pendidikan. Jakarta: Kencana

Sulistyaningsih, Annisa dan Rakhmawati, Ellya. 2017. Analisis Kesalahan Siswa Menurut Kastolan Dalam Pemecahan Masalah Matematika. Seminar Matematika Dan Pendidikan Matematika UNY.

Vantina, dkk., 2008. Keadilan Gender dalam Pengambilan Kebijakan: Antara Harapan dan Kenyataan (Studi Kasus pada Sekretariat Daerah Kota Samarinda Tahun 2008). Jurnal Sosial Politika Vol.15(1)

Velentzas, John dan Broni, Georgia. 2014. Communication Cycle: Definition, Process, Models And Examples. (Online) diakses pada 3 Februari 2020. Tersedia: https://studylib.net/doc/8076219/communic ation-cycle--definition--process--modelsand

Wijaya, dkk., 2016. Kemampuan Komunikasi Matematis Siswa Sesuai Dengan Gender Dalam Pemecahan Masalah Pada Materi Balok Dan Kubus (Studi Kasus Pada Siswa Smp Kelas Viii Smp Islam Al-Azhar 29 Semarang). Jurnal Elektronik Pembelajaran Matematika, vol.4 (9) 